\title{
EFEKTIFITAS IMPLEMENTASI METODE AJAR SCL MODEL SMALL GROUP DISCUSSION
}

\author{
Rilla Gantino ${ }^{1}$, Endang Ruswanti ${ }^{2}$, Taufiqurrahman ${ }^{3}$ \\ ${ }^{1,2}$ Fakultas Ekonomi dan Bisnis Universitas Esa Unggul \\ ${ }^{3}$ Fakultas Teknik Universitas Esa Unggul \\ Jalan Arjuna Utara No 9 Kebon Jeruk Jakarta 11510 \\ rilla.gantino@esaunggul.ac.id
}

\begin{abstract}
This study aims to assess the effectiveness of the application of the SCL method with the Small Group Discussion model. SCL implementation in the Advanced Financial Accounting 1 course, Accounting Theory and Financial Statement Analysis is carried out at the Mercu Buana University Accounting Program, the Accounting Theory course is carried out in the Riau University Accounting Program, GCG courses in the Jakarta State University Accounting Program, Accounting Seminar subject in the Accounting Program at Esa Unggul University Jakarta. Implementation of the SCL method by allocating time between the pre-test before the lecture takes place, providing material by the lecturer through the lecture method, providing examples of material implementation at work, student presentations and discussions and ending with a post test. Researchers also confirmed to students and lecturers regarding the implementation of SCL. Based on the results of the pre-test and post-test that were processed, it was found that the SCL teaching method with SGD proved effective because the Asym.Sig (2-tailed) Pre Test and Post Test values were less than 5\%, meaning that there was a difference between the learning outcomes of the PreTest and the post Test. It is concluded that there is an effect of using learning methods on the value of learning outcomes.
\end{abstract}

Keywords : SCL Method, Small Group Discussion Model, Effectiveness

\begin{abstract}
Abstrak
Penelitian bertujuan untuk menilai efektifitas penerapan metode SCL dengan model Small Group Discussion. Implementasi SCL pada mata kuliah Akuntansi Keuangan Lanjutan 1, Teori Akuntansi dan Analisa Laporan Keuangan dilaksanakan pada Program Studi Akuntansi Universitas Mercu Buana Jakarta, mata kuliah Teori Akuntansi dilaksanakan pada Program Studi Akuntansi Universitas Riau, mata kuliah GCG pada Program Studi Akuntansi Universitas Negeri Jakarta, mata kuliah Seminar Akuntansi pada Program Stusi Akuntansi Universitas Esa Unggul Jakarta. Pelaksanaan metode SCL dengan alokasi waktu antara Pre test sebelum kuliah berlangsung, pemberian materi oleh dosen melalui metode ceramah, pemberian contoh implementasi materi di dunia kerja, presentasi mahasiswa dan diskusi serta diakhiri dengan post test. Peneliti juga melakukan konfirmasi kepada mahasiswa dan dosen terkait pelaksanaan SCL. Berdasarkan hasil pre test dan post test yang diolah untuk melihat apakah ada perbedaan antara hasil test sebelum tindakan dengan setelah tindakan, diperoleh hasil bahwa metode ajar SCL dengan SGD terbukti efektif dan menunjukkan hasil Asym.Sig (2tailed) Pre Test dan Post Test bernilai lebih kecil dari 5\% artinya ada perbedaan antara hasil belajar untuk PreTest dan post Test. Disimpulkan bahwa ada pengaruh penggunaan metode pembelajaran terhadap nilai hasil belajar.
\end{abstract}

Kata kunci :SCL Method, Small Group Discussion Model, Effectiveness

\section{Pendahuluan}

Teori belajar humanistic menem-patkan mahasiswa sebagai makluk yang memiliki potensi. Potensi-potensi terse-but digunakan dalam mencari makna dalam kehidupannya melalui proses belajar. Aunurrahman (2016: 35) me-nyatakan bahwa belajar adalah suatu proses yang dilakukan individu untuk memperoleh suatu perubahan tingkah laku yang baru secara keseluruhan, sebagai hasil 
pengalaman individu itu sendiri di dalam interaksi dengan lingkungannya. Belajar adalah peru-bahan tingkah laku sebagai akibat adanya interaksi antara stimulus dan respon ((Moh Suardi, 2018). Menurut Cronbach (Aggarwal J.C., 2014:47), learning is shown by change in behavior as a result of experience.

Tujuan belajar adalah membentuk pemahaman seseorang terhadap apa yang dipelajari. Pemahaman dari pem-belajar akan menempatkan pembelajar pada posisi stratejik (Moh Suardi, 2018). Cara belajar di perguruan tinggi meru-pakan cara belajar orang dewasa, atau dalam istilah psikologi disebut andragogi. Andragogi pertama kali dipopulerkan oleh Knowles pada 1986. Mahasiswa di-posisikan sebagai subjek aktif yang memiliki kemampuan untuk meren-canakan, menentukan arah, memilih bahan atau materi yang bermanfaat bagi dirinya, memilih cara terbaik untuk belajar, menganalisis dan menyimpul-kan, serta mampu mengambil manfaat dari pendidikan. Cara belajar andaragogi menuntut maha-siswa memiliki kemandirian dan tanggung jawab terhadap perilaku belajar yang dipilih dan memiliki konsekuensi pada pencapaian hasil bela-jar (Hiryanto, 2017).

Faktor-faktor yang mempengaruhi kemauan seseorang (mahasiswa/siswa) untuk melakukan sesuatu adalah motivasi. motivasi dapat dikatakan seba-gai keseluruhan daya penggerak dalam diri mahasiswa yang menimbulkan kegiatan be-lajar, yang menjamin kelangsungan kegiatan belajar dan yang memberikan arah kegiatan belajar sehingga tujuan yang dikehendaki oleh subyek belajar itu sendiri dapat tercapai. Motivasi dapat muncul karena adanya faktor dari dalam diri (internal) dan faktor dari luar diri (eksternal). Faktor eksternal biasanya terlihat dalam proses belajar selama seseorang lebih menekankan peran lingkungan sekolah, lingkungan masyarakat serta lingkungan keluarga dalam setiap keputusan perilakunya. Sedangkan faktor internal yang muncul dari dalam diri siswa berupa kondisi kesehatan (health condition), intelegensi dan bakat (intelligence and talent), minat (interest), motivasi (motiva-tion), dan gaya belajar (learning style) (Hapnita et al., 2017). Untuk itu diperlukan system pembelajaran yang tepat untuk menum-buhkan motivasi.
Meskipun telah dilakukan sosia-lisasi mengenai penerapan $\mathrm{SCL}$, namun dosen-dosen di beberapa perguruan tinggi masih menggunakan sistem pem-belajarannya yang bersifat satu arah, yaitu pemberian materi oleh dosen. Sistem pembelajaran tersebut dikenal dengan model Teacher Centereded Lear-ning (TCL). Sistem ini menjadikan maha-siswa pasif karena hanya mendengarkan kuliah sehingga kreativitas mereka kurang terpupuk atau bahkan cenderung tidak kreatif.

Mahasiswa adalah sekelompok manusia yang beranjak dewasa, mereka tidak hanya memiliki perubahan dari segi fisik namun juga dari segi psikologis. Pola pikir mahasiswa mulai kritis, mereka tidak hanya memikirkan keinginan sema-ta tapi mereka memikirkan tentang apa yang dibutuhkan. Metode pembelajaran yang bersifat satu arah membuat maha-siswa memiliki ruang gerak yang terbatas dalam memilih apa yang ingin dipelajari dan ditelusurinya. Oleh karena itu perlu dilakukan perubahan dalam model pem-belajaran yang selama ini dilakukan.

Usaha meningkatkan kualitas dan mutu pendidikan dapat dilakukan dengan kegiatan belajar-mengajar yang baik. Perlu perubahan paradigma dan inovasi dalam proses pembelajaran Perubahan pendekatan dalam pembelajaran dari TCL menjadi SCL adalah perubahan paradigma, yaitu per-ubahan dalam cara memandang beberapa hal dalam pembelajaran, yakni pengetahuan, belajar, dan pembelajaran. Secara ope-rasional, di dalam SCL para mahasiswa me-miliki keleluasaan untuk mengembangkan segenap potensinya (cipta, rasa dan karsa), mengeksplorasi bidang/imu yang diminati-nya, membangun pengetahuan serta kemu-dian mencapai kompetensinya melalui proses pembelajaran aktif, interaktif, kolabo-ratif, kooperatif, kontekstual dan mandiri.

Beberapa penelitian mengenai efektifitas metode SCL telah banyak dilaku-kan oleh peneliti sebelumnya. Penelitian Angela, dkk (Angela et al., 2017) meghasilan bahwa penerapan SCL dengan Collaborative Learning terbukti sebagai metode pembe-lajaran yang efek-tif. Sebelumnya penelitian Mutmainah (Siti Mutmainah, 2008) meng-hasilkan bahwa SCL dengan cooperative learning ini dapat mengoptimalkan potensi inte-lektual, sosial dan 
emosional maha-siswa. Selanjutnya Rismawati dn Jasman (Rismawati. Jumawan Jasman, 2014) me-nunjukkan hasil bahwa Metode SCL dengan Kooperatif berbasis kasus berpengaruh signifikan terhadap pemahaman matakuliah perpajakan. Penerapan student-centered learning dan penerapan case-based learning berpengaruh secara tidak signifikan terkait pemaham-an mahasiswa pada Akuntansi Keperilakuan namun penerapan coope-rative learning berpengaruh secara signifikan terkait pemahaman mahasiswa pada Akuntansi Keperilakuan (Moerista, 2015). Zahara dan Zalida (Zalida, Zahara, 2016) melakukan penelitian SCL pada mata kuliah Sistem Akuntansi dengan hasil bahwa SCL dengan SGD, Role Play dan Problem Based Learning memiliki nilai mutu yang baik dan Discovery Learning serta Contextual Instruction menghasil-kan mutu sangat baik. Penelitian yang dilakukan oleh Komang, dkk (Saputra \& Larasdiputra, Ni Made Intan, Priliandani Putu Dian, 2019) menghasilkan bahwa penerapan metode pembelajaran berba-sis kasus dan motivasi, berpengaruh positif signifikan terhadap pemahaman akuntansi sektor publik, dan dibuktikan bahwa kecerdasan emosi mampu memo-derasi pengaruh penerapan metode pem-belajaran berbasis kasus dan motivasi me-nuju pemahaman akuntansi sektor publik.

Penelitian ini merupakan replikasi dari penelitian sebelumnya namun pene-liti menggunakan model SGD dalam mengimplementasikan SCL dengan pemantauan pada mata kuliah Teori Akuntansi, Akuntansi Keuangan Lanjutan 1, GCG, Seminar Akun-tansi dan Analisa Laporan Keuangan. SGD dipilih sebagai focus karena peneliti selain mengajarkan kemandirian dalam proses belajar, peneliti juga memfokuskan diri untuk membantu mahasiswa dalam memahami materi ajar agar memudahkan mahasis-wa dalam memahami kerangka teori dalam membuat tugas akhir atau karya ilmiah (Skripsi).

\section{Kerangka Teori}

Persaingan di era Masyarakat Ekono-mi ASEAN (MEA) dan tantangan kompleks di abad 21 menjadikan Perguruan tinggi melakukan perubahan kurikulum sesuai UndangUndang No 12 tahun 2012 tentang Pendidikan Tinggi dan
Peraturan Menteri Riset Teknologi dan Pendidikan Tinggi No 44 tahun 2015 tentang Standar Nasional Pendidikan Tinggi (SN Dikti). Kurikulum Pendidikan Tinggi ini merombak semua perguruan tinggi untuk berjalan seiring dengan Kerangka Kualifikasi Nasional Indonesia (KKNI) menuju kualitas sumber daya manusia Indonesia yang memiliki perjenjangan dalam kualifikasinya dan mencapai rumusan capaian pembelajaran (Learning Outcomes). Sesuai ketetap-an nasional, lulusan program sarjana paling rendah harus memiliki capaian "kemampuan" yang setara dengan "capaian pembelajaran" yang dirumus-kan pada jenjang 6 KKNI, Magister setara jenjang 8, dan seterusnya.

Capaian pembelajaran lulusan (CPL) dalam Kurikulum Pendidikan Tinggi menuntut adanya empat aspek yakni aspek sikap, pengetahuan, keterampilan umum, dan keterampilan khusus seperti yang dinyatakan dalam SN-Dikti. Dan untuk menuntaskan CPL ini dibutuhkan metode pembelajaran yang tepat sebagai prinsip utama yaitu metode yang berpusat pada mahasiswa sedangkan metode lain sebagai pelengkap dalam proses pembelajaran. Metode pembela-jaran yang berpusat pada mahasiswa ini bisa disebut dengan metode SCL (Student Centered Learning).

Student Centered Learning didefi-nisikan sebagai salah satu cara belajar yang membuat mahasiswa menjadi bagian penting atau bagian utama atau berpengaruh pada isi dari materi, kegiatan, dan materi itu sendiri serta kecepatan berpengaruh dalam belajar. Melalui metode pembelajaran ini, mahasiswa mengambil peran utama atau menjadi pusat dalam proses pembela-jaran, maka apapun yang bersangkutan dengan materi pembelajaran mahasiswa harus mandiri dalam mencari sumber - sumber dan referensi belajar dengan bimbingan dari dosen. Maka dosen ter-sebut dapat disebut juga fasilitator yang berperan untuk memfasilitasi apa yang telah mahasiswa cari. Dibandingkan dengan sistem pembelajaran Teacher Centered Learning (TCL) yang berpusat pada Dosen sebagai sumber informasi, Student Centered Learning (SCL) membuat pemahaman mahasiswa lebih dalam dan lebih spesifik mengenai bidang yang ditekuni dengan menjadikan mahasiswa 
sebagai pusat pembelajaran, sehingga pada akhirnya dapat mening-katkan kualitas mahasiswa itu sendiri.

Student Centered Learning (SCL) adalah salah satu metode pembelajaran yang berpusat pada mahasiswa. Pende-katan ini cukup efektif karena mem-berikan ruang kebebasan dan kesem-patan kepada peserta didik untuk menggali sendiri ilmu pengetahuannya dengan banyak sumber referensi yang dapat ia akses sehingga nantinya maha-siswa akan mendapat pengetahuan yang jauh lebih mendalam (deep learning) dan mampu meningkatkan kualitas mahasis-wa. Hal ini di dukung oleh adanya teori konstruktivisme Vigotsky (Santrock, 2015) yang menjadi dasar bahwa maha-siswa memperoleh pengetahuan karena keaktifan mahasiswa itu sendiri.

Metode pembelajaran yang dilaksanakan adalah Student Centered Lear-ning (SCL). Metode pengajaran pada SCL diantaranya adalah Collaborative Lear-ning (CL) (Kaasila R., \& Lauriala, 2010), (Keser, H \& Ozdamli, 2012), Cooperative learning (Baghchegni N., Koohestani H.R. \& Rezaei, 2011), Constructivist Learning (Stefan $L, 2012$ ), Case Studies (Popil I, 2011), Contextual Learning dan lainnya

$\mathrm{SCL}$ (Student Centered Learning) memiliki potensi untuk mendorong maha-siswa belajar lebih aktif, mandiri, sesuai dengan irama belajarnya masing-masing, sesuai dengan perkembangan usia peserta didik, irama belajar ma-hasiswa tersebut perlu dipandu agar terus dinamis dan mempunyai tingkat kompetensi yang tinggi. Beberapa model pembelajaran $\mathrm{SCL}$ adalah sebagai berikut:

\section{a. Small Group Discussion (SGD)}

Metode diskusi merupakan model pembelajaran yang melibatkan antara kelompok mahasiswa dan kelompok mahasiswa atau kelompok mahasiswa dan pengajar untuk menganalisa, menggali atau memperde-batkan topik atau permasalahan tertentu. Dengan metode ini pengajar harus, (1) membuat rancangan bahan diskusi dan aturan diskusi. (2) menjadi moderator dan seka-ligus mengulas pada setiap akhir sesi dis-kusi. Sedangkan mahasiswa (1) mem-bentuk kelompok (5 -10) mahasiswa, (2) memilih bahan diskusi, (3) mempresen-tasikan

paper

dan

mendiskusikannya di kelas.

\section{b. Role-Play and Simulation}

Metode ini berbentuk interaksi antara dua atau lebih mahasiswa tentang suatu topik atau kegiatan dengan menampilkan simbol-simbol atau peralatan yang menggantikan proses, kejadian, atau sistem yang sebe-narnya. Jadi dengan model ini mahasiswa mempelajari sesuatu (sistem) dengan menggunakan model. Dengan metode ini pengajar harus, (1) merancang situasi atau kegiat-an yang mirip dengan sesungguhnya, bisa berupa; bermain peran, model, dan komputer, (2) membahas kinerja maha-siswa. Sedangkan mahasiswa (1) mem-pelajari dan menjalankan suatu peran yang ditugaskan, (2) memperaktekkan atau mencoba berbagai model yang telah disiapkan (komputer, prototife, dan lain-lain).

\section{c. Discovery Learning}

Metode ini berbentuk pemberian tugas belajar atau penelitian kepada mahasis-wa dengan tujuan supaya mahasiswa dapat mencari sendiri jawabannya tampa bantuan pengajar Dengan metode ini pengajar harus, (1) menyediakan data atau metode untuk menelusuri pengetahuan yang akan dipe-lajari mahasiswa, (2) memeriksa dan memberikan ulasan terhadap hasil belajar mahasiswa. Sedangkan mahasiswa (1) mencari, mengumpulkan, dan menyusun infor-masi yang ada untuk mendeskripsikan suatu pengetahuan yang baru, (2) mem-presentasikan secara verbal dan non verbal.

\section{d. Self-Directed Learning}

Metode ini berbentuk pemberian tugas belajar kepada mahasiswa, seperti tugas membaca dan membuat ringkasan. Dengan metode ini pengajar harus, (1) memotivasi dan memfasilitasi mahasiswa, (2) membe-rikan arahan, bimbingan dan umpan balik kemajuan belajar mahasiswa. Sedangkan mahasiswa (1) merencanakan kegiatan bela-jar, melaksanakan, dan menilai pengalaman belajar sendiri, (2) inisiatif belajar dari maha-siswa sendiri.

\section{e. Cooperative Learning}


Pembelajaran koperatif sesuai dengan fitrah manusia sebagai makhluk sosial yang penuh ketergantungan dengan otrang lain, mempunyai tujuan dan tanggung jawab bersama, pembegian tugas, dan rasa senasib. Saling mem-bantu dan berlatih beinteraksikomu-nikasi-sosialisasi karena koperatif adalah miniature dari hidup bermasyarakat, dan belajar menyadari kekurangan dan kelebihan masing-masing. Jadi model pembelajaran koperatif adalah kegiatan pembelajaran dengan cara berkelompok untuk bekerja sama saling membantu mengkontruksu konsep, menyelesaikan persoalan, atau inkuiri. Menurut teori dan pengalaman agar kelompok kohesif (kompakpartisipatif), tiap anggota kelompok terdiri dari $4-5$ orang, mahasiswa hete-rogen (kemampuan, gender, karekter), ada control dan fasilitasi, dan meminta tanggung jawab hasil kelompok berupa laporan atau presentasi. Sintaks pembelajaran koperatif adalah informasi, pengarahan strategi, membentuk kelompok heterogen, kerja kelompok, presentasi hasil kelompok, dan pelaporan. Pada metode ini pengajar harus, (1) merancang dan memonitor proses be-lajar mahasiswa, (2) menyiapkan kasus atau masalah untuk diselesaikan mahasiswa se-cara berkelompok. Sedangkan maha-siswa: (1) membahas dan menyimpulkan masalah atau tugas yang diberikan secara ber-kelompok (2) melakukan koordinasi dalam kelompok.

\section{Contextual Learning (CL)}

Pembelajaran kontekstual adalah pembelajaran yang dimulai dengan sajian atau tanya jawab lisan (ramah, terbuka, nego-siasi) yang terkait dengan dunia nyata kehidupan mahasiswa (daily life modeling), sehingga akan terasa manfaat dari materi yang akan disajikan, motivasi belajar muncul, dunia pikiran mahasiswa menjadi konkret, dan suasana menjadi kondusif - nyaman dan menyenangkan. Prinsip pembelajaran kontekstual adalah aktivitas mahasiswa, mahasiswa melakukan dan mengalami, tidak hanya menonton dan mencatat, dan pengembangan kemampuan sosialisasi. Ada tujuh indikator pembelajaran kontekstual sehingga bisa dibedakan dengan model lainnya, yaitu modeling (pemusatan perhatian, motivasi, penyampaian kompe-tensi tujuan, pengarahan, petunjuk, rambu-rambu), questioning (eksplorasi, membim-bing, menuntun, mengarahkan, mengem-bangkan, evaluasi, inkuiri, generalisasi), learning community (seluruh mahasiswa partisipatif dalam belajar kelompok atau individual, minds-on, hands-on, mencoba, mengerjakan), inquiry (identifikasi, inves-tigasi, hipotesis, konjektur, generalisasi, menemukan), constructivism (membangun pemahaman sendiri, mengkonstruksi konsep aturan, analisis-sintesis), reflection (review, rangkuman, tindak lanjut), authentic assessment (penilaian selama proses dan sesudah pembelajaran, penilaian terhadap setiap aktvitas-usaha mahasiswa, penilaian portofolio, penilaian seobjektif-objek-tifnya dari berbagai aspek dengan berbagai cara). Metode ini pengajar harus, (1) menyusun tugas untuk studi mahasiswa terjun di lapangan, (2) menjelaskan bahan kajian yang bersifat teori dan mengkaitkan dengan situasi nyata atau kerja profesional. Sedangkan mahasiswa (1) melakukan studi lapangan atau terjun di dunia nyata untuk mem-pelajari kesesuaian teori (2) memba-has konsep atau teori yang berkaitan dengan situasi nyata.

\section{Problem Based Learning (PBL)}

Kehidupan adalah identik dengan mengha-dapi masalah. Model pembelajaran ini melatih dan mengembangkan kemampuan untuk menyelesaikan masalah yang berorientasi pada masalah otentik dari ke-hidupan aktual mahasiswa, untuk merang-sang kemampuan berpikir tingkat tinggi. Kondisi yang tetap harus dipelihara adalah suasana kondusif, terbuka, negosiasi, demokratis, suasana nyaman dan menye-nangkan agar mahasiswa dapat berpikir optimal. Indikator model pembelajaran ini adalah meta-kognitif, elaborasi (analisis), interpretasi, induksi, identifikasi, investigasi, eksplo-rasi, konjektur, sintesis, generalisasi, dan inkuiri. Dengan metode ini pengajar ha-rus, (1) merangsang tugas belajar dengan berbagai alternatif metode penyelesaian masalah (2) sebagai fasilitator dan moti-vator. Sedangkan mahasiswa (1) belajar dengan menggali atau mencari informasi (inquiry), serta memanfaatkan informasi tersebut untuk memecahkan masalah faktual yang sedang 
dihadapi, (2) menganalisis stra-tegi pemecahan masalah.

\section{Collaborative Learning (CbL)}

Metode ini memungkinkan mahasiswa untuk mencari dan menemukan jawaban sebanyak mungkin, saling berinteraksi untuk menggali semua kemungkinan yang ada. Dengan metode ini pengajar harus, (1) Merancang tugas yang bersifat open ended, (2) Sebagai fasilitator dan motivator. Sedangkan maha-siswa (1) Membuat rancangan proses dan bentuk penilaian berdasarkan konsensus kelom-pok sendiri (2) Bekerja sama dengan anggota kelompoknya dalam menger-jakan tugas.

\section{Project Based Learning (PjBL)}

Metode ini memberikan tugas-tugas yang harus diselesaikan oleh mahasiswa dengan mencari sumber pustaka sendiri. Pengajar harus, (1) merumuskan tugas dan mela-kukan proses pembimbingan dan asesmen, (2) sebagai fasilitator dan motivator. Mahasiswa (1) mengerjakan tugas (berupa proyek) yang telah dirancang secara sistematis (2) menunjukkan kinerja dan mempertanggung-jawabkan hasil kerja di forum.

\section{Metode Penelitian}

Penelitian ini merupakan penelitian deskriptif kualitatif. Implemetnasi metode $\mathrm{SCL}$ dengan model SGD, Self Directed Learning dan Contextual Learning dilakukan pada mahasiswa yang mengambil mata kuliah GCG ( Prodi Akuntansi UNJ), Teori Akuntansi (Prodi Akuntansi UNRI dan Mercu Buana Jakarta), Analisa Laporan Keuangan (Prodi Mercu Buana Jakarta), Akuntansi Keuangan Lanjutan 1 (Prodi Mercu Buana Jakarta) dan Seminar Akuntansi (Prodi Akuntansi Univ Esa Unggul). Pemilihan ini terkait dengan ke-sepakatan mitra yang akan mem-bantu. Tim peneliti berdasarkan hasil diskusi meru-muskan implementasi SCL model SGD mellui pemberian materi dengan ceramah $40 \%$ dari total jam mengajar setiap pertemuan, dengan menggunakan referensi wajib dan memberikan contoh implementasi terkait konsep $20 \%$ dari total jam mengajar setiap pertemuan, memberikan tugas membaca dan mereview hasil penelitian sebelumnya terkait dengan materi ajar, dosen me-nentukan topik penelitian yang hatus dibaca dan direview (tugas kelompok maksimal anggota kempok 3 orang), membahas hasil pene-litian sebelumnya terkait tugas dari materi seblumnya, yang dibahas adalah (bobot penggunaan waktu 40\%): pen-dahuluan, teori yang mendukung, data yang dibutuhkan dan hasil dan pembahasan.

\section{Hasil dan Pembahasan}

Sebagai proses awal, tim peneliti menyusun rencana proses pembelajaran sebagai acuan dalam mengimplemen-tasikan SCL dengan model SGD. Adapun proses pembelajaran yang diterapkan adalah sebagai berikut :

Tabel 1. Proses Pembelajaran

\begin{tabular}{|c|c|c|c|c|}
\hline No & Implementasi & $\begin{array}{c}\text { Yang dilakukan } \\
\text { Mahasiswa }\end{array}$ & Yang dilakukan Dosen & $\begin{array}{c}\text { Model } \\
\text { Belajar }\end{array}$ \\
\hline 1 & $\begin{array}{l}\text { Persiapan } \\
\text { kuliah }\end{array}$ & -- & $\begin{array}{l}\text { - Membuat RPS } \\
\text { - Menyiapkan referensi buku } \\
\text { - Menyiapkan } 14 \text { hasil } \\
\text { penelitian sebelumnya } \\
\text { (jurnal) yang terkait topik } \\
\text { perkuliahan } \\
\text { - Membuat Soal Pre Test dan } \\
\text { Post Test untuk setiap } \\
\text { pertemuan (minimal } 4 \text { kali } \\
\text { pertemuan) }\end{array}$ & \\
\hline
\end{tabular}


Jurnal Ekonomi : Journal of Economic p-ISSN: 2087-8133 | e-ISSN: 2528-326X

\begin{tabular}{|c|c|c|c|c|}
\hline No & Implementasi & $\begin{array}{c}\text { Yang dilakukan } \\
\text { Mahasiswa }\end{array}$ & Yang dilakukan Dosen & $\begin{array}{l}\text { Model } \\
\text { Belajar }\end{array}$ \\
\hline 2 & $\begin{array}{l}\text { Penjelas-an } \\
\text { Materi oleh } \\
\text { Dosen }\end{array}$ & $\begin{array}{l}\text { Mendengarkan dan } \\
\text { Melakukan }\end{array}$ & $\begin{array}{l}\text { - Sebelum perkuliahan } \\
\text { berlangsung, dosen } \\
\text { memberikan pretest dan } \\
\text { saat akhir penjelasan } \\
\text { materi memberi-kan post } \\
\text { test } \\
\text { - Menjelaskan materi dari } \\
\text { buku referensi dan } \\
\text { mengkaitkan materi } \\
\text { dengan situasi nyata } \\
\text { didunia kerja professional } \\
\text { atau kewirausahaan } \\
\text { - Mendiskusikan kasus atau } \\
\text { case yang ada di buku } \\
\text { refersni dalam bentuk } \\
\text { soal hitungan atau case } \\
\text { selain hitungan }\end{array}$ & $\begin{array}{l}\text { Ceramah } \\
\text { dan Contex- } \\
\text { tual Lear- } \\
\text { ning }\end{array}$ \\
\hline 3 & $\begin{array}{l}\text { Presen-tasi } \\
\text { kelompok }\end{array}$ & $\begin{array}{l}\text { - Mahasiswa membuat } \\
\text { kelompok dengan } \\
\text { memperhatikan jumlah } \\
\text { peserta kelas dan jumlah } \\
\text { pertemuan dalam } \\
\text { semester.Setiap } \\
\text { kelompok akan } \\
\text { mempresentasikan } 1 \\
\text { topik penelitian yang } \\
\text { sudah disiapkan oleh } \\
\text { dosen } \\
\text { - Setiap kelompok akan } \\
\text { mempelajari isi jurnal } \\
\text { dan mempresen-tasikan } \\
\text { isi jurnal tersebut }\end{array}$ & $\begin{array}{l}\text { - Dosen akan menjadi } \\
\text { moderator } \\
\text { - Dosen akan menjelaskan } \\
\text { keterkaitan topik } \\
\text { penelitian yang } \\
\text { dipresentasikan } \\
\text { mahasiswa dengan topik } \\
\text { materi kuliah } \\
\text { - Menjawab pertanyaan dari } \\
\text { mahasiswa } \\
\text { - Memberikan penilian atas } \\
\text { presentasi yang } \\
\text { dilekuakan oleh } \\
\text { mahasiswa }\end{array}$ & $\begin{array}{l}\text { - Small } \\
\text { Group } \\
\text { Discussion }\end{array}$ \\
\hline 4 & $\begin{array}{l}\text { Mengumpulkan } \\
\text { tugas }\end{array}$ & $\begin{array}{l}\text { - Mahasiswa mengerjakan } \\
\text { tugas yang diberikan } \\
\text { oleh dosen }\end{array}$ & $\begin{array}{l}\text { - Memeriksa dan menilai tgas } \\
\text { yang diberikan oleh dosen }\end{array}$ & $\begin{array}{l}\text { - Self-direc- } \\
\text { ted lear- } \\
\text { ning }\end{array}$ \\
\hline
\end{tabular}

Pelaksanaan $\mathrm{SCl}$ dalam penelitian ini adalah penerapan Small Group Discussion dengan rincian seperti dalamm tabel diatas terutama ditujukan agar membantu mahasiswa dalam menyelesaikan tugas akhir atau skripsi, karena banyak mahasiswa kurang paham dasar teori topik tugas akhir yang mereka pilih. Pemantauan pelaksanaan SCL dilakukan di prodi akuntansi 4 kampus yaitu, Universitas Negeri Jakarta dengan mata kuliah Good Corporate Governance, Universitas Riau,
Universitas dengan mata kuliah Teori Akuntansi, Universitas Mercu Buana dengan mata kuliah Analisa Laporan Keuangan, Teori Akuntansi dan Akuntansi Keuangan Lanjutan 1 dan Universitas Esa Unggul dengan mata kuliah Seminar Akuntansi. Mata kuliah ini dipilih dengan dasar banyaknya tugas akhir dengan topik yang terkiat dengan teori di mata kuliah tersebut.

Hasil penilaian efektifitas pembe-lajaran SCL di 4 kampus adalah sebagai berikut : 
Hasil Wilcoxon Rank MK GCG (Akuntansi UNJ)

Tabel 2

Hasil Olah Data MK GCG

Ranks

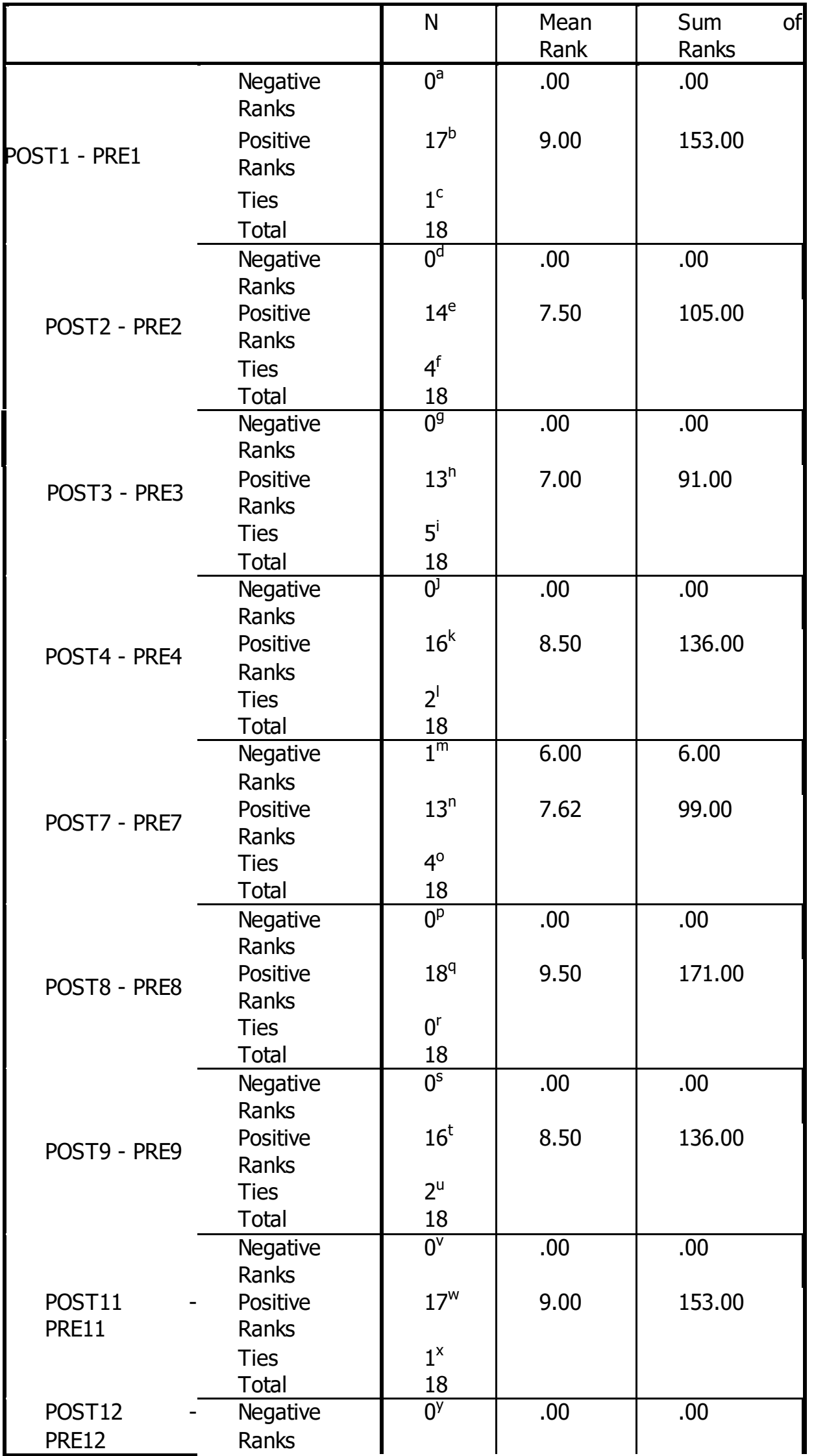




\begin{tabular}{|l|c|l|l|}
\hline \multicolumn{1}{|c|}{ Ranks } & \\
\hline & $\mathrm{N}$ & $\begin{array}{l}\text { Mean } \\
\text { Rank }\end{array}$ & $\begin{array}{l}\text { Sum } \\
\text { Ranks }\end{array}$ \\
\hline Positive & $14^{\mathrm{z}}$ & 7.50 & 105.00 \\
Ranks & & & \\
Ties & $4^{\text {aa }}$ & & \\
Total & 18 & & \\
\hline
\end{tabular}

Negative Rank untuk nilai Pre Test dan Post

Test bernilai nol kecuali untuk Pre Test dan Post Test ke 7. Nilai nol menunjukkan tidak adanya penurunan nilai (pengurangan dari nilai Pre Test ke Post Test.

Nilai Positive Rank Pre Test dan Post Test 1 adalah 17 dengan rata-rata peningkatan adalah 9 dengan jumlah ranking positive adalah 153. Ties atau kesamaan nilai Pre test dengan Post Test pertama ini adalah 1.

Nilai Positive Rank Pre Test dan Post Test 2 adalah 14 dengan rata-rata peningkatan adalah 7.5 dengan jumlah ranking positive adalah 105 . Ties atau kesamaan nilai Pre test dengan Post Test pertama ini adalah 4.

Nilai Positive Rank Pre Test dan Post Test 3 adalah 13 dengan rata-rata peningkatan adalah 7 dengan jumlah ranking positive adalah 91. Ties atau kesamaan nilai Pre test dengan Post Test pertama ini adalah 5.

Nilai Positive Rank Pre Test dan Post Test 4 adalah 16 dengan rata-rata peningkatan adalah 8.5 dengan jumlah ranking positive adalah 136. Ties atau kesamaan nilai Pre test dengan Post Test pertama ini adalah 3.
Nilai Positive Rank Pre Test dan Post Test 7 adalah 13 dengan rata-rata peningkatan adalah 7.62 dengan jumlah ranking positive adalah 99. Ties atau kesamaan nilai Pre test dengan Post Test pertama ini adalah 4.

Nilai Positive Rank Pre Test dan Post Test 8 adalah 18 dengan rata-rata peningkatan adalah 9.5 dengan jumlah ranking positive adalah 171. Ties atau kesamaan nilai Pre test dengan Post Test pertama ini adalah 0.

Nilai Positive Rank Pre Test dan Post Test 9 adalah 16 dengan rata-rata peningkatan adalah 8.5 dengan jumlah ranking positive adalah 136. Ties atau kesamaan nilai Pre test dengan Post Test pertama ini adalah 2.

Nilai Positive Rank Pre Test dan Post

Test 11 adalah 17 dengan rata-rata peningkatan adalah 9 dengan jumlah ranking positive adalah 153 . Ties atau kesamaan nilai Pre test dengan Post Test pertama ini adalah 1.

Nilai Positive Rank Pre Test dan Post Test 12 adalah 14 dengan rata-rata peningkatan adalah 7.5 dengan jumlah ranking positive adalah 105 . Ties atau kesamaan nilai Pre test dengan Post Test pertama ini adalah 4.

Tabel 3

Tabel Test Statistik

Test Statistics ${ }^{a}$

\begin{tabular}{|l|l|l|l|l|l|}
\hline & POST1 & -POST2 - PRE2 & POST3 - PRE3 & POST4 - PRE4 & POST7 - PRE7 \\
\hline PRE1 & $-3.658^{\mathrm{b}}$ & $-3.332^{\mathrm{b}}$ & $-3.314^{\mathrm{b}}$ & $-3.548^{\mathrm{b}}$ & $-2.945^{\mathrm{b}}$ \\
Asymp. Sig. (2-tailed) & .000 & .001 & .001 & .000 & .003 \\
\hline
\end{tabular}

Test Statistics $^{a}$

\begin{tabular}{|l|l|l|l|l|}
\hline & POST8 - PRE8 & POST9 - PRE9 & POST11 - PRE11 & POST12 - PRE12 \\
\hline Z & $-3.759^{\mathrm{b}}$ & $-3.541^{\mathrm{b}}$ & $-3.650^{\mathrm{b}}$ & $-3.336^{\mathrm{b}}$ \\
Asymp. Sig. (2-tailed) & .000 & .000 & .000 & .001 \\
\hline
\end{tabular}

a. Wilcoxon Signed Ranks Test

b. Based on negative ranks.

Berdasarkan tabel diatas, diperoleh ada perbedaan antara hasil belajar untuk bahwa Asym.Sig (2-tailed) semua pada semua PreTest dan post Test. Disimpulkan bahwa ada Pre Test dan Post Test bernilai 0.000 artinya 
Jurnal Ekonomi : Journal of Economic p-ISSN: 2087-8133 | e-ISSN: 2528-326X

pengaruh penggunaan metode pembela-jaran terhadap nilai hasil belaja

1. Hasil Wilcoxon Rank MK Teori Akuntansi FEB Akuntansi UNRI

Tabel 4. Hasil Olah Data MK Teori Akuntansi

\begin{tabular}{|c|c|c|c|c|}
\hline \multicolumn{5}{|c|}{ Ranks } \\
\hline & & $\mathrm{N}$ & Mean Rank & Sum of Ranks \\
\hline \multirow{4}{*}{ POST3 - PRE3 } & Negative Ranks & $2^{\mathrm{a}}$ & 3.50 & 7.00 \\
\hline & Positive Ranks & $32^{b}$ & 18.38 & 588.00 \\
\hline & Ties & $3^{c}$ & & \\
\hline & Total & 37 & & \\
\hline \multirow{4}{*}{ POST5 - PRE5 } & Negative Ranks & $3^{d}$ & 2.50 & 7.50 \\
\hline & Positive Ranks & $34^{\mathrm{e}}$ & 20.46 & 695.50 \\
\hline & Ties & $0^{\dagger}$ & & \\
\hline & Total & 37 & & \\
\hline \multirow{4}{*}{ POST7 - PRE7 } & Negative Ranks & $2^{g}$ & 5.50 & 11.00 \\
\hline & Positive Ranks & $30^{\mathrm{h}}$ & 17.23 & 517.00 \\
\hline & Ties & $5^{1}$ & & \\
\hline & Total & 37 & & \\
\hline \multirow{4}{*}{ POST9 - PRE9 } & Negative Ranks & $4^{3}$ & 5.00 & 20.00 \\
\hline & Positive Ranks & $31^{k}$ & 19.68 & 610.00 \\
\hline & Ties & 2 & & \\
\hline & Total & 37 & & \\
\hline \multirow{4}{*}{ POST11 - PRE11 } & Negative Ranks & $2^{m}$ & 6.50 & 13.00 \\
\hline & Positive Ranks & $31^{n}$ & 17.68 & 548.00 \\
\hline & Ties & $4^{\circ}$ & & \\
\hline & Total & 37 & & \\
\hline
\end{tabular}

Negative Rank muncul disemua nilai Pre test dan Post Test. Secara detail negative rank Pre Test dan post Test 3 adalah 2, Pre Test dan Post Test 5 adalah 3, Pre Test dan Post Test 7 adalah 2, Pre Test dan Post Test 9 adalah 4, Pre Test dan Post Test 11 adalah 2.

Nilai Positive Rank Pre Test dan Post Test 3 adalah 32 dengan rata-rata pening-katan adalah 18.38 dengan jumlah ranking positive adalah 588. Ties atau kesamaan nilai Pre test dengan Post Test pertama ini adalah 3

Nilai Positive Rank Pre Test dan Post Test 5 adalah 34 dengan rata-rata peningkatan adalah 9.5 dengan jumlah ranking positive adalah 171. Ties atau kesamaan nilai Pre test dengan Post Test pertama ini adalah 0.
Nilai Positive Rank Pre Test dan Post Test 7 adalah 30 dengan rata-rata peningkatan adalah 17.23 dengan jumlah ranking positive adalah 517. Ties atau kesamaan nilai Pre test dengan Post Test pertama ini adalah 5.

Nilai Positive Rank Pre Test dan Post Test 9 adalah 31 dengan rata-rata peningkatan adalah 19.68 dengan jumlah ranking positive adalah 610. Ties atau kesamaan nilai Pre test dengan Post Test pertama ini adalah 2.

Nilai Positive Rank Pre Test dan Post Test 11 adalah 31 dengan rata-rata peningkatan adalah 17.68 dengan jumlah ranking positive adalah 548. Ties atau kesamaan nilai Pre test dengan Post Test pertama ini adalah 4.

Tabel 5. Hasil Test Statistik

Test Statistics $^{\text {a }}$

\begin{tabular}{|l|r|r|r|r|r|}
\hline & POST3 - PRE3 & POST5 - PRE5 & POST7 - PRE7 & POST9 - PRE9 & POST11 - PRE11 \\
\hline Z & $-5.008^{\mathrm{b}}$ & $-5.218^{\mathrm{b}}$ & $-4.772^{\mathrm{b}}$ & $-4.853^{\mathrm{b}}$ & $-4.819^{\mathrm{b}}$ \\
$\begin{array}{l}\text { Asymp. Sig. } \\
\text { (2-tailed) }\end{array}$ & .000 & .000 & .000 & .000 & .000 \\
\hline
\end{tabular}

a. Wilcoxon Signed Ranks Test

b. Based on negative ranks. 
Berdasarkan tabel diatas, diperoleh bahwa Asym.Sig (2-tailed) semua pada semua Pre Test dan Post Test bernilai 0.000 artinya ada perbedaan antara hasil belajar untuk PreTest dan post Test. Disimpulkan bahwa ada pengaruh penggunaan metode pembelajaran terhadap nilai hasil belajar.

2. Hasil Wilcoxon Rank MK Teori Akuntansi (Akuntansi FEB Universitas Mercu Buana)

Tabel 6

Hasil Olah Data MK Teori Akuntansi

\begin{tabular}{|c|c|c|c|c|}
\hline \multicolumn{5}{|c|}{ Ranks } \\
\hline & & $\mathrm{N}$ & Mean Rank & Sum of Ranks \\
\hline \multirow{4}{*}{ POST1 - PRE1 } & Negative Ranks & $2^{a}$ & 2.50 & 5.00 \\
\hline & Positive Ranks & $15^{b}$ & 9.87 & 148.00 \\
\hline & Ties & $3^{c}$ & & \\
\hline & Total & 20 & & \\
\hline \multirow{4}{*}{ POST3 - PRE3 } & Negative Ranks & $0^{d}$ & .00 & .00 \\
\hline & Positive Ranks & $18^{\mathrm{e}}$ & 9.50 & 171.00 \\
\hline & Ties & $2^{f}$ & & \\
\hline & Total & 20 & & \\
\hline \multirow{4}{*}{ POST5 - PRE5 } & Negative Ranks & $0^{g}$ & .00 & .00 \\
\hline & Positive Ranks & $19^{h}$ & 10.00 & 190.00 \\
\hline & Ties & $1^{\mathrm{i}}$ & & \\
\hline & Total & 20 & & \\
\hline \multirow{4}{*}{ POST7 - PRE7 } & Negative Ranks & $0^{j}$ & .00 & .00 \\
\hline & Positive Ranks & $20^{k}$ & 10.50 & 210.00 \\
\hline & Ties & 0 & & \\
\hline & Total & 20 & & \\
\hline
\end{tabular}

Negative Rank hanya muncul nilai Pre test dan Post Test 1 . Nilai Positive Rank Pre Test dan Post Test 1 adalah 15 dengan ratarata peningkatan adalah 9.87 dengan jumlah ranking positive adalah 148 . Ties atau kesamaan nilai Pre test dengan Post Test pertama ini adalah 3

Nilai Positive Rank Pre Test dan Post Test 3 adalah 18 dengan rata-rata peningkatan adalah 9.5 dengan jumlah ranking positive adalah 171. Ties atau kesamaan nilai Pre test dengan Post Test pertama ini adalah 2.
Nilai Positive Rank Pre Test dan Post Test 5 adalah 19 dengan rata-rata peningkatan adalah 10 dengan jumlah ranking positive adalah 190. Ties atau kesamaan nilai Pre test dengan Post Test pertama ini adalah 1.

Nilai Positive Rank Pre Test dan Post Test 7 adalah 20 dengan rata-rata peningkatan adalah 10.5 dengan jumlah ranking positive adalah 210. Ties atau kesamaan nilai Pre test dengan Post Test pertama ini adalah 0. Tabel berikut adalah hasil test statisiknya :

Tabel 7

Hasil Test Statistik

Test Statistics ${ }^{\mathrm{a}}$

\begin{tabular}{|c|c|c|c|c|}
\hline & $\begin{array}{c}\text { POST1 - } \\
\text { PRE1 }\end{array}$ & $\begin{array}{l}\text { POST3 - } \\
\text { PRE3 }\end{array}$ & $\begin{array}{l}\text { POST5 - } \\
\text { PRE5 }\end{array}$ & $\begin{array}{l}\text { POST7 - } \\
\text { PRE7 }\end{array}$ \\
\hline $\begin{array}{l}\text { Z } \\
\text { Asymp. Sig. (2- } \\
\text { tailed) }\end{array}$ & $\begin{array}{r}-3.406^{\mathrm{b}} \\
.001\end{array}$ & $\begin{array}{r}-3.740^{\mathrm{b}} \\
.000\end{array}$ & $\begin{array}{r}-3.854^{\mathrm{b}} \\
.000\end{array}$ & $\begin{array}{r}-3.944^{\mathrm{b}} \\
.000\end{array}$ \\
\hline
\end{tabular}

a. Wilcoxon Signed Ranks Test

b. Based on negative ranks.

Berdasarkan tabel diatas, diperoleh bahwa Asym.Sig (2-tailed) semua pada semua Pre
Test dan Post Test 1 bernilai 0.001 lebih kesil dari $5 \%$ atau 0.05 dan Pre test dan Post Test 
Jurnal Ekonomi : Journal of Economic p-ISSN: 2087-8133 | e-ISSN: 2528-326X

lainnya bernilai 0.000 artinya ada perbedaan antara hasil belajar untuk PreTest dan post Test. Disimpulkan bahwa ada pengaruh penggunaan metode pembelajaran terhadap nilai hasil belajar

\section{Hasil Wilcoxon Rank MK Analisa Laporan Keuangan Program Studi Akuntansi FEB Universitas} Mercu Buana

Negative Rank bernilai nol terdapat pada Pre test dan Post Test 5 dan 8, negative rank Pre Test dan Post Test 2,3,4, dan 12 sebanyak 1, selanjutnya negative rank Pre Test dan Post Test 1 sebanyak 2 kali

Nilai Positive Rank Pre Test dan Post Test 1 adalah 37 dengan rata-rata peningkatan adalah 20.31 dengan jumlah ranking positive adalah 751.5. Ties atau kesamaan nilai Pre test dengan Post Test pertama ini adalah 4

Nilai Positive Rank Pre Test dan Post Test 2 adalah 41 dengan rata-rata peningkatan adalah 21.8 dengan jumlah ranking positive adalah 894. Ties atau kesamaan nilai Pre test dengan Post Test pertama ini adalah 1.

Nilai Positive Rank Pre Test dan Post Test 3 adalah 40 dengan rata-rata peningkatan adalah 21.49 dengan jumlah ranking positive adalah 859,5 . Ties atau kesamaan nilai Pre test dengan Post Test pertama ini adalah 2.
Nilai Positive Rank Pre Test dan Post Test 4 adalah 40 dengan rata-rata peningkatan adalah 21.38 dengan jumlah ranking positive adalah 855. Ties atau kesamaan nilai Pre test dengan Post Test pertama ini adalah 2.

Nilai Positive Rank Pre Test dan Post Test 5 adalah 43 dengan rata-rata peningkatan adalah 22 dengan jumlah ranking positive adalah 948. Ties atau kesamaan nilai Pre test dengan Post Test pertama ini adalah 0.

Nilai Positive Rank Pre Test dan Post Test 8 adalah 42 dengan rata-rata peningkatan adalah 21.50 dengan jumlah ranking positive adalah 903 . Ties atau kesamaan nilai Pre test dengan Post Test pertama ini adalah 1.

Nilai Positive Rank Pre Test dan Post Test 12 adalah 42 dengan rata-rata peningkatan adalah 22.49 dengan jumlah ranking positive adalah 944.5. Ties atau kesamaan nilai Pre test dengan Post Test pertama ini adalah 0 .

Tabel hasil olah data sebagai berikut :

Tabel 8

Hasil Olah Data MK Analisa Laporan Keuangan

\begin{tabular}{|c|c|c|c|c|}
\hline \multicolumn{5}{|c|}{ Ranks } \\
\hline & & $\mathrm{N}$ & Mean Rank & Sum of Ranks \\
\hline \multirow{4}{*}{ POST1 - PRE1 } & Negative Ranks & $2^{\mathrm{a}}$ & 14.25 & 28.50 \\
\hline & Positive Ranks & $37^{b}$ & 20.31 & 751.50 \\
\hline & Ties & $4^{c}$ & & \\
\hline & Total & 43 & & \\
\hline \multirow{4}{*}{ POST2 - PRE2 } & Negative Ranks & $1^{\mathrm{d}}$ & 9.00 & 9.00 \\
\hline & Positive Ranks & $41^{\mathrm{e}}$ & 21.80 & 894.00 \\
\hline & Ties & $1^{\dagger}$ & & \\
\hline & Total & 43 & & \\
\hline \multirow{4}{*}{ POST3 - PRE3 } & Negative Ranks & $1^{\mathrm{g}}$ & 1.50 & 1.50 \\
\hline & Positive Ranks & $40^{n}$ & 21.49 & 859.50 \\
\hline & Ties & $2^{\prime}$ & & \\
\hline & Total & 43 & & \\
\hline \multirow{3}{*}{ POST4 - PRE4 } & Negative Ranks & $1^{j}$ & 6.00 & 6.00 \\
\hline & Positive Ranks & $40^{k}$ & 21.38 & 855.00 \\
\hline & Ties & $2^{1}$ & & \\
\hline
\end{tabular}


Jurnal Ekonomi : Journal of Economic p-ISSN: 2087-8133 | e-ISSN: 2528-326X

\begin{tabular}{|l|l|r|r|r|}
\hline & Total & 43 & & \\
\hline \multirow{4}{*}{ POST5 - PRE5 } & Negative Ranks & $0^{\mathrm{m}}$ & .00 & .00 \\
\cline { 2 - 5 } & Positive Ranks & $43^{\mathrm{n}}$ & 22.00 & 946.00 \\
\cline { 2 - 5 } & Ties & $0^{\circ}$ & & \\
\cline { 2 - 5 } & Total & 43 & & .00 \\
\hline \multirow{4}{*}{ POST8 - PRE8 } & Negative Ranks & $0^{\mathrm{p}}$ & .00 & 903.00 \\
\cline { 2 - 5 } & Positive Ranks & $42^{\mathrm{q}}$ & 21.50 & \\
\cline { 2 - 6 } & Ties & $1^{\mathrm{r}}$ & & 1.50 \\
\cline { 2 - 6 } & Total & 43 & & \\
\hline \multirow{4}{*}{ POST12 - PRE12 } & Negative Ranks & $1^{\mathrm{s}}$ & 1.50 & \\
\cline { 2 - 6 } & Positive Ranks & $42^{\mathrm{t}}$ & 22.49 & 944.50 \\
\cline { 2 - 6 } & Ties & $0^{\mathrm{u}}$ & & \\
\cline { 2 - 6 } & Total & 43 & & \\
\hline
\end{tabular}

Tabel hasil statistic adalah sebagai berikut :

\section{Tabel 9}

Tabel Hasil Test Statistik MK Analisa Laporan Keuangan

Test Statistics ${ }^{\mathrm{a}}$

\begin{tabular}{|l|c|r|r|r|r|r|r|}
\hline & \multicolumn{1}{|c|}{$\begin{array}{c}\text { POST1 - } \\
\text { PRE1 }\end{array}$} & $\begin{array}{c}\text { POST2 - } \\
\text { PRE2 }\end{array}$ & $\begin{array}{c}\text { POST3 - } \\
\text { PRE3 }\end{array}$ & $\begin{array}{c}\text { POST4 - } \\
\text { PRE4 }\end{array}$ & $\begin{array}{c}\text { POST5 - } \\
\text { PRE5 }\end{array}$ & $\begin{array}{r}\text { POST8 - } \\
\text { PRE8 }\end{array}$ & $\begin{array}{r}\text { POST12 - } \\
\text { PRE12 }\end{array}$ \\
\hline Z & $-5.100^{\mathrm{b}}$ & $-5.550^{\mathrm{b}}$ & $-5.587^{\mathrm{b}}$ & $-5.531^{\mathrm{b}}$ & $-5.733^{\mathrm{b}}$ & $-5.696^{\mathrm{b}}$ & $-5.726^{\mathrm{b}}$ \\
Asymp. Sig. & .000 & .000 & .000 & .000 & .000 & .000 & .000 \\
(2-tailed) & & & & & & & \\
\hline
\end{tabular}

a. Wilcoxon Signed Ranks Test

b. Based on negative ranks.

Berdasarkan tabel diatas, diperoleh PreTest dan post Test. Disimpulkan bahwa ada bahwa Asym.Sig (2-tailed) semua pada semua pengaruh penggunaan metode pembelajaran Pre Test dan Post Test bernilai 0.000 artinya terhadap nilai hasil belajar. ada perbedaan antara hasil belajar untuk

Hasil Wilcoxon dan Test Statistik MK Akuntansi Keuangan Lanjutan 1 Prodi Akuntansi FEB Universitas Mercu Buana

Tabel 10

Hasil Olah Data MK Akuntansi Keuangan Lanjutan 1

\section{Ranks}

\begin{tabular}{|c|c|c|c|c|}
\hline & & $\mathrm{N}$ & Mean Rank & Sum of Ranks \\
\hline \multirow{4}{*}{ POST1 - PRE1 } & Negative Ranks & $2^{\mathrm{a}}$ & 7.50 & 15.00 \\
\hline & Positive Ranks & $24^{b}$ & 14.00 & 336.00 \\
\hline & Ties & $5^{c}$ & & \\
\hline & Total & 31 & & \\
\hline \multirow{4}{*}{ POST2 - PRE2 } & Negative Ranks & $0^{\mathrm{d}}$ & .00 & .00 \\
\hline & Positive Ranks & $29^{\mathrm{e}}$ & 15.00 & 435.00 \\
\hline & Ties & $2^{f}$ & & \\
\hline & Total & 31 & & \\
\hline \multirow{4}{*}{ POST9 - PRE9 } & Negative Ranks & $0^{9}$ & .00 & .00 \\
\hline & Positive Ranks & $30^{h}$ & 15.50 & 465.00 \\
\hline & Ties & $1^{\prime}$ & & \\
\hline & Total & 31 & & \\
\hline \multirow{4}{*}{ POST10 - PRE10 } & Negative Ranks & $0^{j}$ & .00 & .00 \\
\hline & Positive Ranks & $32^{k}$ & 17.50 & 579.00 \\
\hline & \begin{tabular}{|l|} 
Ties \\
\end{tabular} & $1^{\prime}$ & & \\
\hline & Total & 31 & & \\
\hline \multirow{3}{*}{ POST11 - PRE11 } & Negative Ranks & $0^{m}$ & .00 & .00 \\
\hline & Positive Ranks & $26^{n}$ & 13.50 & 351.00 \\
\hline & Ties & $5^{\circ}$ & & \\
\hline
\end{tabular}


Negative Rank hanya terdapat pada Pre test dan Post Test 1 sebanyak 2 kali.

Nilai Positive Rank Pre Test dan Post Test 1 adalah 24 dengan rata-rata peningkatan adalah 14 dengan jumlah ranking positive adalah 336 . Ties atau kesamaan nilai Pre test dengan Post Test pertama ini adalah 5

Nilai Positive Rank Pre Test dan Post Test 2 adalah 29 dengan rata-rata peningkatan adalah 15 dengan jumlah ranking positive adalah 435. Ties atau kesamaan nilai Pre test dengan Post Test pertama ini adalah 2.

Nilai Positive Rank Pre Test dan Post Test 9 adalah 30 dengan rata-rata peningkatan adalah 15.5 dengan jumlah ranking positive adalah 465. Ties atau kesamaan nilai Pre test dengan Post Test pertama ini adalah 1.

Adapun tabel statistic test nya adalah sebagai berikut :

Tabel 11. Hasil Test Statistik MK Akuntansi Keuangan Lanjutan 1

Test Statistics $^{\mathbf{a}}$

\begin{tabular}{|l|r|r|r|r|r|}
\hline & \multicolumn{1}{|c|}{$\begin{array}{c}\text { POST1 - } \\
\text { PRE1 }\end{array}$} & $\begin{array}{c}\text { POST2 - } \\
\text { PRE2 }\end{array}$ & \multicolumn{1}{c|}{$\begin{array}{c}\text { POST9 - } \\
\text { PRE9 }\end{array}$} & \multicolumn{1}{c|}{$\begin{array}{c}\text { POST10 - } \\
\text { PRE10 }\end{array}$} & \multicolumn{1}{c|}{$\begin{array}{c}\text { POST11 - } \\
\text { PRE11 }\end{array}$} \\
\hline Z & $-4.167^{\mathrm{b}}$ & $-4.777^{\mathrm{b}}$ & $-4.835^{\mathrm{b}}$ & $-4.835^{\mathrm{b}}$ & $-4.505^{\mathrm{b}}$ \\
Asymp. Sig. (2-tailed) & .000 & .000 & .000 & .000 & .000 \\
\hline
\end{tabular}

a. Wilcoxon Signed Ranks Test

b. Based on negative ranks.

Berdasarkan tabel diatas, diperoleh bahwa Asym.Sig (2-tailed) semua pada semua Pre Test dan Post Test bernilai 0.000 artinya ada perbedaan antara hasil belajar untuk PreTest dan post Test. Disimpulkan bahwa ada pengaruh penggunaan metode pembelajaran terhadap nilai hasil belajar.

Hasil Wilcoxon dan Test Statistik MK Seminar Akuntansi Prodi Akuntansi FEB Universitas Esa Unggul

Tidak terdapat Negative Rank..

Nilai Positive Rank Pre Test dan Post Test 1 adalah 9 dengan rata-rata peningkatan adalah 5 dengan jumlah ranking positive adalah 45 . Ties atau kesamaan nilai Pre test dengan Post Test pertama ini adalah 1

Nilai Positive Rank Pre Test dan Post Test 3 adalah 9 dengan rata-rata peningkatan adalah 5 dengan jumlah ranking positive adalah 45 .
Nilai Positive Rank Pre Test dan Post Test 10 adalah 32 dengan rata-rata peningkatan adalah 17.5 dengan jumlah ranking positive adalah 579. Ties atau kesamaan nilai Pre test dengan Post Test pertama ini adalah 0.

Nilai Positive Rank Pre Test dan Post Test 11 adalah 26 dengan rata-rata peningkatan adalah 13.5 dengan jumlah ranking positive adalah 351. Ties atau kesamaan nilai Pre test dengan Post Test pertama ini adalah 5 .

Tabel berikut menunjukkan hasil olah data efektifitas pembelajaran MK Akuntansi Keuangan Lanjutan 1 Prodi FEB Universitas Mercu Buana
Ties atau kesamaan nilai Pre test dengan Post Test pertama ini adalah 1.

Nilai Positive Rank Pre Test dan Post Test 5 adalah 9 dengan rata-rata peningkatan adalah 15.5 dengan jumlah ranking positive adalah 45 . Ties atau kesamaan nilai Pre test dengan Post Test pertama ini adalah 1.

Nilai Positive Rank Pre Test dan Post Test 7 adalah 10 dengan rata-rata peningkatan adalah 5.5 dengan jumlah ranking positive adalah 55 . Ties atau kesamaan nilai Pre test dengan Post Test pertama ini adalah 0.

Nilai Positive Rank Pre Test dan Post Test 9 adalah 5.5 dengan rata-rata peningkatan adalah 5.5 dengan jumlah ranking positive adalah 55. Ties atau kesamaan nilai Pre test dengan Post Test pertama ini adalah 0.

Nilai Positive Rank Pre Test dan Post Test 11 adalah 10 dengan rata-rata peningkatan adalah 13.5 dengan jumlah ranking positive adalah 55 . 
Ties atau kesamaan nilai Pre test dengan Post Ties atau kesamaan nilai Pre test dengan Post Test pertama ini adalah 0. Test pertama ini adalah 0.

Nilai Positive Rank Pre Test dan Post Test1 13 Tabel berikut menunjukkan hasil olah data adalah 10 dengan rata-rata peningkatan adalah efektifitas pembelajaran MK Seminar Akuntansi 5.5 dengan jumlah ranking positive adalah 55. Prodi Akuntansi FEB Universitas Esa Unggul

Tabel 12

Hasil Olah Data MK MK Seminar Akuntansi

Ranks

\begin{tabular}{|c|c|c|c|c|}
\hline & & $\mathrm{N}$ & $\begin{array}{l}\text { Mean } \\
\text { Rank }\end{array}$ & $\begin{array}{l}\text { Sum of } \\
\text { Ranks }\end{array}$ \\
\hline \multirow{4}{*}{ POST1 - PRE1 } & Negative Ranks & $0^{\mathrm{a}}$ & .00 & .00 \\
\hline & Positive Ranks & $9^{b}$ & 5.00 & 45.00 \\
\hline & Ties & $1^{\mathrm{c}}$ & & \\
\hline & Total & 10 & & \\
\hline \multirow{3}{*}{ POST3 - PRE3 } & Negative Ranks & $0^{d}$ & .00 & .00 \\
\hline & Positive Ranks & $9^{\mathrm{e}}$ & 5.00 & 45.00 \\
\hline & Ties & $\begin{array}{c}1 \\
10\end{array}$ & & \\
\hline \multirow{4}{*}{ POST5 - PRE5 } & Negative Ranks & $0^{9}$ & .00 & .00 \\
\hline & Positive Ranks & $9^{h}$ & 5.00 & 45.00 \\
\hline & Ties & $1^{\prime}$ & & \\
\hline & Total & 10 & & \\
\hline \multirow{3}{*}{ POST7 - PRE7 } & Negative Ranks & $0^{\top}$ & .00 & .00 \\
\hline & Positive Ranks & $10^{\kappa}$ & 5.50 & 55.00 \\
\hline & Total & 10 & & \\
\hline \multirow{4}{*}{ POST9 - PRE9 } & Negative Ranks & $0^{\mathrm{m}}$ & .00 & .00 \\
\hline & Positive Ranks & $10^{n}$ & 5.50 & 55.00 \\
\hline & Ties & $0^{\circ}$ & & \\
\hline & Total & 10 & & \\
\hline \multirow{4}{*}{ POST11 - PRE11 } & Negative Ranks & $0^{\mathrm{p}}$ & .00 & .00 \\
\hline & Positive Ranks & $10^{9}$ & 5.50 & 55.00 \\
\hline & Ties & $0^{r}$ & & \\
\hline & $\begin{array}{l}\text { Total } \\
\text { Negative Ranks }\end{array}$ & $\begin{array}{r}10 \\
0^{s}\end{array}$ & 00 & 00 \\
\hline \multirow{3}{*}{ POST13 - PRE13 } & Positive Ranks & $10^{t}$ & 5.50 & 55.00 \\
\hline & Ties & $0^{\mathrm{u}}$ & & \\
\hline & Total & 10 & & \\
\hline
\end{tabular}

Adapun tabel statistik test nya adalah sebagai berikut :

Tabel 13

Test Statistics $^{a}$

Hasil Test Statistik MK Seminar Akuntansi

\begin{tabular}{|c|c|c|c|c|c|c|c|}
\hline & $\begin{array}{c}\text { POST1 - } \\
\text { PRE1 }\end{array}$ & $\begin{array}{c}\text { POST3 - } \\
\text { PRE3 }\end{array}$ & $\begin{array}{c}\text { POST5 - } \\
\text { PRE5 }\end{array}$ & $\begin{array}{l}\text { POST7 } \\
\text { - PRE7 }\end{array}$ & $\begin{array}{c}\text { POST9 - } \\
\text { PRE9 }\end{array}$ & $\begin{array}{c}\text { POST11 - } \\
\text { PRE11 }\end{array}$ & $\begin{array}{c}\text { POST13 - } \\
\text { PRE13 }\end{array}$ \\
\hline $\begin{array}{l}\text { Z } \\
\text { Asymp. Sig. (2-tailed) }\end{array}$ & $\begin{array}{r}-2.687^{b} \\
.007\end{array}$ & $\begin{array}{r}-2.699^{b} \\
.007\end{array}$ & $\begin{array}{r}-2.687^{\mathrm{b}} \\
.007\end{array}$ & $\begin{array}{r}-2.825^{b} \\
.005\end{array}$ & $\begin{array}{r}-2.821^{b} \\
.005\end{array}$ & $\begin{array}{r}-2.850^{b} \\
.004\end{array}$ & $\begin{array}{r}-2.840^{b} \\
.005\end{array}$ \\
\hline
\end{tabular}

a. Wilcoxon Signed Ranks

b. Based on negative ranks

Berdasarkan tabel diatas, diperoleh Pre Test dan Post Test bernilai lebih kecil dari bahwa Asym.Sig (2-tailed) semua pada semua nilai signifikasi $5 \%$ artinya ada perbedaan 
antara hasil belajar untuk PreTest dan post Test. Disimpulkan bahwa ada pengaruh penggunaan metode pembelajaran terhadap nilai hasil belajar.

Tim mengumpulkan pendapat dari maha-siswa atas implementasi metode ajar yang dilaksanakan. Berdasarkan hasil kuesioner yang disebarkan ke mahasiswa yang mengikuti proses pembelajaran tersebut adalah sebagai berikut :

a. Gender pengisi kuesioner :

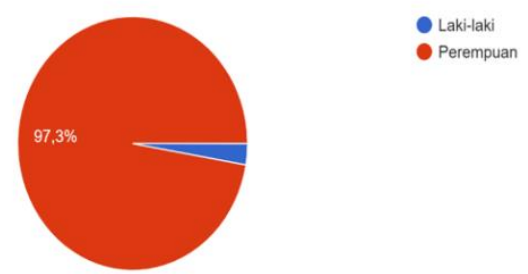

Gambar 1. Gender Pengisi Kuesioner

b. Status Pengisi Kuesioner

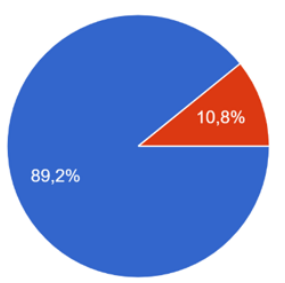

- Mahasiswa

Mahasiswa dan Pekerja

Gambar 2

Status Pengisi Kuesioner

Berdasarkan hasil kuesioner me-ngenai penerapan SCL dengan repsondennya mahasiswa, terlihat bahwa mahasiswa aktif dalam perkuliahan dengan tugas dan kewajiban mempersiapkan diri sebelum perkuliahan (pernyataan no 1-9). Untuk itu mahasiswa menggunakan website fakultas dan prodi untuk mecari tahu tentang perkuliahan, mengggunakan jaringan internet, dan mengirimkan tugas-tugas melalui email.

Melalui pernyataan yang disampaikan ke mahasiswa (no 10-18), mahasiswa juga menyadari bahwa tugas yang diberikan merupakan proses pembelajaran. Mahasiswa berusaha untuk memenuhi semua tugas yang diberikan oleh dosen. Hal ini juga tergambar dari jawaban yang diberikan oleh mahasiswa (untuk butir pernyataan no 22-28). Mahasiswa merasa puas dengan implememtasi SCL oleh dosen. Mereka me-rasakan manfaatnya dan memahami bahwa materi ajar, hasil penelitian sebelumnya merupakan sumber bahan untuk mengerjakan tugas akhir. Namun mahasiswa masih merasakan bahwa peran dosen dalam megajar dengan pemaparan materi oleh dosen masih menempati porsi yang tinggi menurut persepsi mahasiswa.

Berdasarkan hasil uji efektifitas melalui uji $t$ (Wilcoxon) diperoleh hasil untuk seluruh mata kuliah yang mengim-plementasikan metode ajar SCL dengan menerapkan pre dan post test, memberikan tugas bacaan hasil penelitian sebelumnya, mempresentasikan dan pemberian tugas lain memberikan hasil bahwa tingkat signifikasinya $<0.05$ dan hasil jawaban mahasiswa maka diperoleh kesimpulan bahwa metode ajar tersebut telah efektif.

Tim juga mengumpulkan pendapat atas implementasi metode ajar yang dilaksanakan pada kampus mitra. Ber-dasarkan hasil kuesioer yang ditujukan kepada dosen mitra, diperoleh hasil yang juga menunjukkan bahwa dosen telah menja-lankan SCL dengan sungguhsungguh. Meskipun masih ditemui kendala seperti kurang beraninya maahsiswa menyampaikan pendapat, masih terdapatnya mahasiswa yang menjalankan tugas yang diberikan dosen dengan maksud tidak menambah pama-haman. Dosen merasakan dengan penerapan Metode SCL beperngaruh terhadap nilai akhir $(50 \%)$ hal ini diperoleh dari kuesioner yang diberikan kepada dosen mitra. Dosen juga merasa puas dengan metode SCL yang dilaksanakan, adanya manfaat bagi mahasiswa dengan mmebrikan tugas mempelajari penelian sebelumnya.

Selanjutnya tim juga mengumpulkan pendapat dari dosen-dosen yang tidak dalam range kerjasama dalam penelitian ini. Tujuan kuesioner adalah untuk mengetahui pendapat dosen-dosen atas metode SCL dan bagaimana penerapan di kampus masing-masing.

Hasil pengumpulan pendapat adalah sebagai berikut :

1. Kuesioner disi oleh 52 orang responden dari 48 perguruan tinggi, dengan rincian 3 perguruan tinggi negeri dan 45 perguruan tinggi swasta

2. Jenis Kelamin/Gender responden adalah - Perempuan $56,4 \%$

- Laki-laki 43.6\% 
Jurnal Ekonomi : Journal of Economic p-ISSN: 2087-8133 | e-ISSN: 2528-326X

Tabel 15

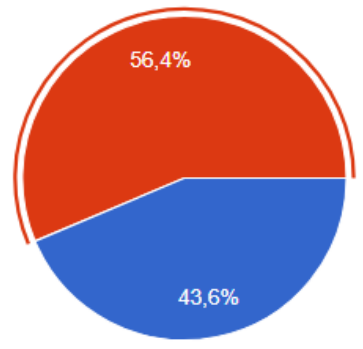

Mata Kuliah Yang diampu oleh Dosen

\begin{tabular}{|c|l|r|}
\hline No & \multicolumn{1}{|c|}{ Mata Kuliah } & \multicolumn{1}{|c|}{$\%$} \\
\hline 1 & Akuntansi Keuangan Lanjutan 1 & 18.2 \\
\hline 2 & Analisa Laporan Keuangan & 9.1 \\
\hline 3 & Teori Akuntansi & 16.4 \\
\hline 4 & GCG & 7.3 \\
\hline 5 & Seminar Akuntansi & 16.4 \\
\hline 6 & Tidak Ada Satupun & 49.1 \\
\hline 7 & Semua & 1.8 \\
\hline
\end{tabular}

Gambar 3. Gender Responden Dosen Non Mitra

\section{Responden $94.5 \%$ adalah dosen tetap}

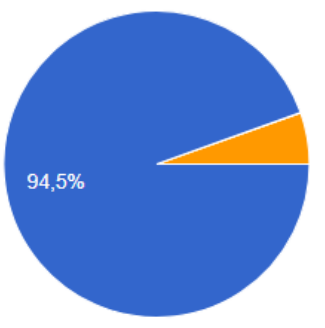

Gambar 4

Status Dosen Responden Dosen Non Mitra

4. Lama bekerja di universitas

Tabel 14. Lama Bekerja

\begin{tabular}{|l|r|}
\hline Lama Bekerja & Jumlah Responden \\
\hline $0-5$ & 16 \\
\hline $6-10$ & 8 \\
\hline $11-15$ & 6 \\
\hline $16-20$ & 10 \\
\hline $21-25$ & 6 \\
\hline $26-30$ & 5 \\
\hline Diatas 30 & 1 \\
\hline & 52 \\
\hline
\end{tabular}

5. Mata kuliah yang sama dengan Mata Kuliah yang diajarkan oleh Dosen Mitra adalah sebagai berikut :

6. Hasil pengumpulan pendapat dari dosen yang tidak menjadi mitra adalah sebagai berikut :

Berdasarkan hasil kuesioner terkait penerapan $\mathrm{SCL}$, yang diberikan kepada dosendosen selain dosen kampus mitra, diperoleh informasi bahwa :

1. Sebagian besar dosen masih memanfaatkan metode ceramah,

2. Mahasiswa merasakan manfaat atas pemberian tugas mempelajri hasil penelitian sebelumnya,

3. Dosen merasa puas dengan metode $\mathrm{SCL}$ yang mereka kerjakan,

4. Dosen juga telah memberikan penjelasan atas jurnal harus dpelajari dan materi ajar yang diberikan bahwa topik materi ajar dan tugas bermanfaat terkait dengan variable pada tugas akhir mahasiswa.

5. Dosen juga memastikan bahwa mahasiswa bersungguh-sungguh mengerjakan tugas yang diberikan oleh dosen.

Hasil penelitian ini mendukung beberapa penelitian sebelumnya yang menghasilkan bahwa metode SCL efektif dalam memotivasi mahasiswa untuk belajat dan menambah pemahaman atas materi ajar. Penelitian yang dimaksud adalah penelitian Angela, dkk (Angela et al., 2017) meghasilan bahwa penerapan SCL dengan Collaborative Learning terbukti sebagai metode pembelajaran yang efektif. Sebelumnya penelitian Mutmainah (Siti Mutmainah, 2008), penelitian Rismawati dn Jasman (Rismawati. Jumawan Jasman, 2014) , Zahara dan Zalida (Zalida, Zahara, 2016) dan penelitian yang dilakukan oleh Komang, dkk (Saputra \& Larasdiputra, Ni Made Intan, Priliandani Putu Dian, 2019). 


\section{Simpulan}

Berdasarkan hasil implementasi SCL model SGD pada mata kuliah Akuntansi Keuangan Lanjutan 1, Teori Akuntansi, GCG, Analisa Laporan Keuangan, dan Seminar Akuntansi, dan didasarkan hasil olah data berupa data nilai pre test dan post test pada setiap mata kuliah tersebut, diperoleh hasil bahwa penerapan hasil implementasi $\mathrm{SCL}$ tersebut efektif dan berdasarkan hasil pengumpulan informasi melalui kuesioner, bahwa dosen dan mahasiswa merasa puaas dengan metode SCL yang dilaksanakan dan dosen juga memastikan mahasiswa bersungguh-sungguh mengerjakan tugasyang diberikan oleh dosen (tugas membaca jurnal, mempresentasikan dan diskusi).

Melalui hasil penelitian ini, tim peneliti mendukung diterapkan nya metode SCL dengan model SGD dan diharapkan untuk implementasi berikutnya mahasiswa diperkenankan untuk mencari sendiri hasil penelitian sebelumnya. Hal ini tentunya memberikan motivasi kepada mahasiswa untuk menjalin komunikasi dengan dosen pengampu mata kuliah terkait kriteria pemilihan hasil penelitian sebelumnya yang sesuai dengan materi ajar, disamping itu setiap kelompok akan berkomunikasi dengan kelompok lainnya yang ditugasi dengan topik materi ajar yang sama dalam hal memilih penelitian sebelumnya agar tidak terjadi pemilihan judul dan peneliti yang sama.

\section{Daftar Pustaka}

Aggarwal J.C. (2014). Essentials of Educational Technology (third). Vikas Publishing House.

Angela, A., Krismawan, R., Ekonomi, F., Studi, P., \& Maranatha, A. K. (2017). Penerapan Metode Pembelajaran Kooperatif Berbasis Kasus Terhadap Efektivitas Pembelajaran Mahasiswa Akuntansi Universitas Kristen Maranatha. 9(November), 104-113.

Baghchegni N., Koohestani H.R., \&, \& Rezaei, K. (2011). A Comparison of the cooperative learning and traditional learning methods in theory classes on nursing student communication skill with patient at clinical setting. Nurse
Education Today, Science Direct, 31, 877-882,.

Hapnita, W., Abdullah, R., Gusmareta, Y., \& Rizal, F. (2017). Faktor Internal Dan Eksternal Yang Dominan Siswa Kelas Xi Teknik Gambar Bangunan Smk N 1 Padang Tahun 2016 / 2017. CIVED, 5(1).

Hiryanto. (2017). Pedagogi, Andragogi Dan Heutagogi Serta Implikasinya Dalam Pemberdayaan Masyarakat. Dinamika Pendidikan, XXII.

Kaasila R., \& Lauriala, A. (2010). Toward a collaborative, interactionist model of teacher change. Teaching and Teacher Education, Elsevier Ltd, 26, 854-862,.

Keser, H \& Ozdamli, F. (2012). Another view to importance of teaching methods in curiculum: collaborative learning and students critical thinking disposition. Procedia - Social and Behaviour Sciences, Science Direct, 46, 32663270.

Moerista, J. V. (2015). Pengaruh Penerapan Metode Student-Centered Learning, Cooperative Learning, Case-Based Learning Terkait Pemahaman Mahasiswa pada Pembelajaran Akuntansi Keperilakuan. Ekonomi \& Bisnis Universitas Dian Nusantara.

Moh Suardi. (2018). Belajar \& Pembelajaran. Deepublish ,Yogyakarta.

Popil I. (2011). Promotion af critical thinking by using case studies as teaching method; Nurse Education Today, Science Direct, 31, 204-207.

Rismawati. Jumawan Jasman. (2014). Efektivitas Pembelajaran Perpajakan. Jurnal Akuntansi, 01(02).

Santrock. (2015). Psikologi Pendidikan (2nd ed.). Kencana Prenada Media Group. JAKARTA. 
Saputra, K. A. K., \& Larasdiputra, Ni Made Intan, Priliandani Putu Dian, P. G. D. (2019). Case-Based Learning Dalam Pembelajaran Akuntansi Sektor Publik. Aksioma, 18(1), 113-155.

Siti Mutmainah. (2008). Pengaruh Penerapan Metode Pembelajaran Kooperatif Berbasis Kasus Yang Berpusat Pada Mahasiswa Terhadap Efektivitas Pembelajaran Akuntansi Keperilakuan. http://eprints.undip.ac.id/17165/1/SNA1 1Mutamimah.pdf

Stefan L. (2012). Immersive collaborative environment for teaching and learning traditional design. Procedia - Social and Behaviour Sciences, 51, 1056-1060,.

Zalida, Zahara, A. (2016). Analisis Penerapan Model Rancangan Struktur Metode Student Centre Learning ( Scl ) Dalam Mata Kuliah Sistem Akuntansi Dengan Kurikulum Berbasis Kompetensi ( KBK ). Jurnal Akuntansi \& Manajemen, 11(1), 64-79. 